\title{
Re-evaluation of the Mentelle Basin, a polyphase rifted margin basin, offshore southwest Australia: new insights from integrated regional seismic datasets
}

\author{
D. Maloney ${ }^{1}$, C. Sargent ${ }^{1}$, N. G. Direen ${ }^{2,3}$, R. W. Hobbs ${ }^{1}$, and D. R. Gröcke ${ }^{1}$ \\ ${ }^{1}$ Department of Earth Sciences, Durham University, South Road, Durham DH1 3LE, UK \\ ${ }^{2}$ School of Earth Sciences, University of Tasmania, Sandy Bay, Tasmania, 7000, Australia \\ ${ }^{3}$ FrOG Tech Pty Ltd, Blackmans Bay, Tasmania, 7052, Australia
}

Received: 16 December 2010 - Published in Solid Earth Discuss.: 3 February 2011

Revised: 31 May 2011 - Accepted: 2 June 2011 - Published: 7 July 2011

\begin{abstract}
Vintage 2-D (two-dimensional) seismic reflection surveys from the sparsely explored Mentelle Basin (western Australian margin) have been reprocessed and integrated with a recent high-quality 2-D seismic survey and stratigraphic borehole data. Interpretation of these data sets allows the internal geometry of the Mentelle Basin fill and depositional history to be reanalysed and new insights into its formation revealed. Basin stratigraphy can be subdivided into several seismically defined megasequences separated by major unconformities related to both breakup between IndiaMadagascar and Australia-Antarctica in the ValanginianLate Hauterivian and tectonically-driven switches in deposition through the Albian.
\end{abstract}

Resting on the Valanginian-Late Hauterivian breakup unconformity are several kilometre-scale mounded structures that formed during Late Jurassic to Early Cretaceous extension. These have previously been interpreted as volcanic edifices although direct evidence of volcanic feeder systems is lacking. An alternative interpretation is that these features may be carbonate build-ups. The latter interpretation carries significant climatic ramifications since carbonate build-ups would have formed at high palaeolatitude, $\sim 60^{\circ} \mathrm{S}$.

Soon after breakup, initial subsidence resulted in a shallow marine environment and deposition of Barremian-Aptian silty-sandy mudstones. As subsidence continued, thick successions of Albian ferruginous black clays were deposited. Internally, seismic megasequences composed of successions of black clays show previously unresolved unconformities, onlapping and downlapping packages, which reflect a com-

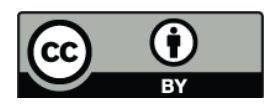

Correspondence to: D. R. Gröcke (d.r.grocke@durham.ac.uk) plex depositional, rifting and subsidence history at odds with their previous interpretation as open marine sediments.

Southwestwards migration of the Kerguelen hotspot led to thermal contraction and subsidence to the present day water depth $(\sim 3000 \mathrm{~m})$. This was accompanied by TuronianSantonian deposition of massive chalk beds, which are unconformably overlain by pelagic Palaeocene-Holocene sediments. This substantial unconformity is related to the diachronous breakup and onset of slow spreading between Australia and Antarctica, which may have led to the reactivation and inversion of basement faults and was followed by rapid seafloor spreading from the Middle Eocene to the present.

\section{Introduction}

The Mentelle Basin is a recently discovered (Borissova, 2002), sparsely explored, deep water (200-4000 m) sedimentary basin that underlies the bathymetric Naturaliste Trough, located between the Naturaliste Plateau and the southern part of the Western Australian Shelf (Figs. 1, 2 and 3). The basin was originally termed the "Naturaliste Trough" (Jongsma and Petkovic, 1977), but this term is now used solely for the bathymetric feature between the Yallingup Shelf and the Naturaliste Plateau (Borissova, 2002; Borissova et al., 2010a) (Figs. 2 and 3). Initial appraisals based on the S18 and "Petrel" seismic surveys map the Mentelle Basin as being slightly elliptical in shape, with minor and major axes $\sim 200 \mathrm{~km}$ east-west and $\sim 220 \mathrm{~km}$ north-south respectively, with an estimated $3 \mathrm{~s}$ two-way travel time (TWT) $(\sim 3 \mathrm{~km})$ of sedimentary fill in the main depocentre (Borissova, 2002; Bradshaw et al., 2003).

Published by Copernicus Publications on behalf of the European Geosciences Union. 


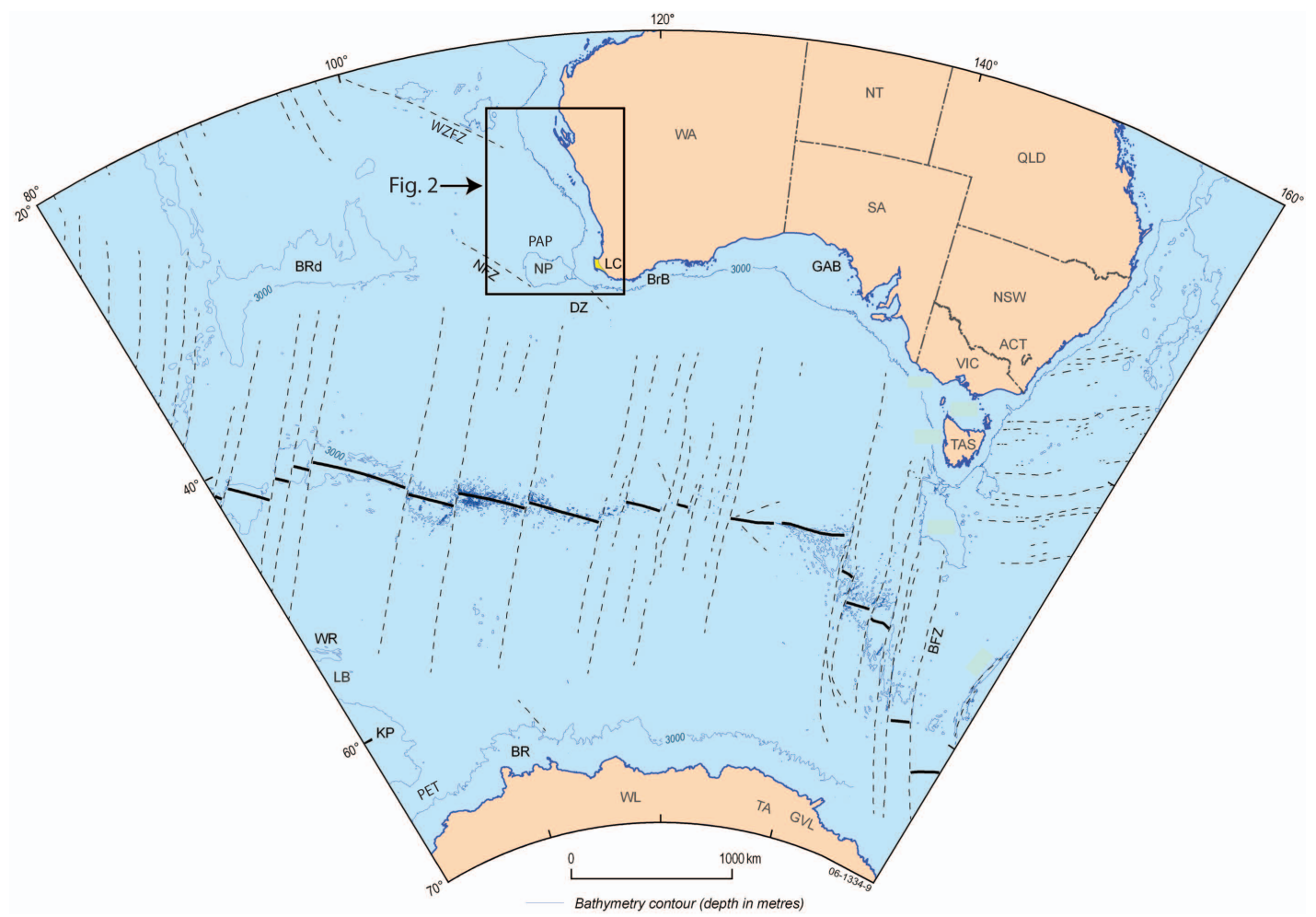

Fig. 1. Regional structural elements map of the Western Australian margin displaying the location of structural features that have led to the development of the Mentelle Basin. BRd = Broken Ridge; BR = Bruce Rise; DZ = Diamantina Zone; N = Naturaliste Plateau; $\mathrm{NFZ}=$ Naturaliste Fracture Zone; LC = Leeuwin Complex; BrB = Bremer Basin; GAB = Great Australian Bight; GC = Gawler Craton; $\mathrm{BFZ}=$ Balleny Fracture Zone; MR = Macquarie Ridge; WR = Williams Ridge; LB = Labuan Basin; KP = (southern) Kerguelen Plateau; WL = Wilkes Land; TA = Terre Adélie; GVL = George V Land. WA = Western Australia; NT = Northern Territory; SA = South Australia; QLD = Queensland; NSW = New South Wales; ACT = Australian Capital Territory; VIC = Victoria; TAS = Tasmania; PET = Princess Elizabeth Trough; WZFZ = Wallaby-Zenith Fracture Zone; PAP = Perth Abyssal Plain (modified from Direen et al., 2011).

A basement ridge in the southern part of the Naturaliste Plateau separates the Mentelle Basin from the Diamantina Zone (DZ) to the south (Halpin et al., 2008) (Fig. 1), whereas in the North, the basin merges with the Perth Abyssal Plain (Fig. 2). Interpretation of seismic and gravity data suggested that the Mentelle Basin probably formed during Late Jurassic-Early Cretaceous rifting (Borissova, 2002; Borissova et al., 2010a, b; Johnston et al., 2010).

In this study, we present the results of the reprocessing and interpretation of the older S18, "Petrel" and S280 2-D data sets, which are combined with more recent high-quality 2-D multi channel seismic data. Interpretation of this revised and expanded dataset allows an appraisal of the structural history of the Mentelle Basin with a greater degree of accuracy and certainty in comparison to previous studies, which were undertaken on a regional scale (Borissova, 2002; Bradshaw et al., 2003). In addition, we have provided insights into paleoenvironemntal conditions prior to, during, and subsequent to Gondwana fragmentation in the Late Cretaceous.

\section{Geological setting}

The western margin of Australia (Figs. 1 and 2) is the northern arm of a triple junction that formed during the final stages of Gondwana breakup (e.g. Powell et al., 1988; Royer and Coffin, 1992; Direen et al., 2007, 2008). The tectonic history of the Mentelle Basin within this milieu is poorly defined (Borissova, 2002; Bradshaw et al., 2003; Borissova et al., 2010a, b), with basin history largely extrapolated from better-studied areas to the north (e.g. the Perth Basin (Fig. 2), Bradshaw et al., 2003) and south (e.g. Diamantina Zone (DZ) (Fig. 1), Beslier et al., 2004; Halpin et al., 2008). After a polycyclic history of continental extension that commenced in the Permo-Carboniferous (Mutter et al., 1989; Metcalfe, 1996; Stagg et al., 2004), Greater India began to break away from Australia-Antarctica in the Argo Abyssal Plain (AP), which lies $\sim 1500 \mathrm{~km}$ to the north of the Mentelle Basin, commencing in the latest Middle Jurassic (Callovian) (Markl, 1978; Mihut and Mueller, 1998). This rift propagated southwards through the Gascoyne, Cuvier and Perth margins during the Early Cretaceous producing a free plate boundary (Valanginian-Hauterivian) (Veevers and Li, 1991; Song and Cawood, 2000). 


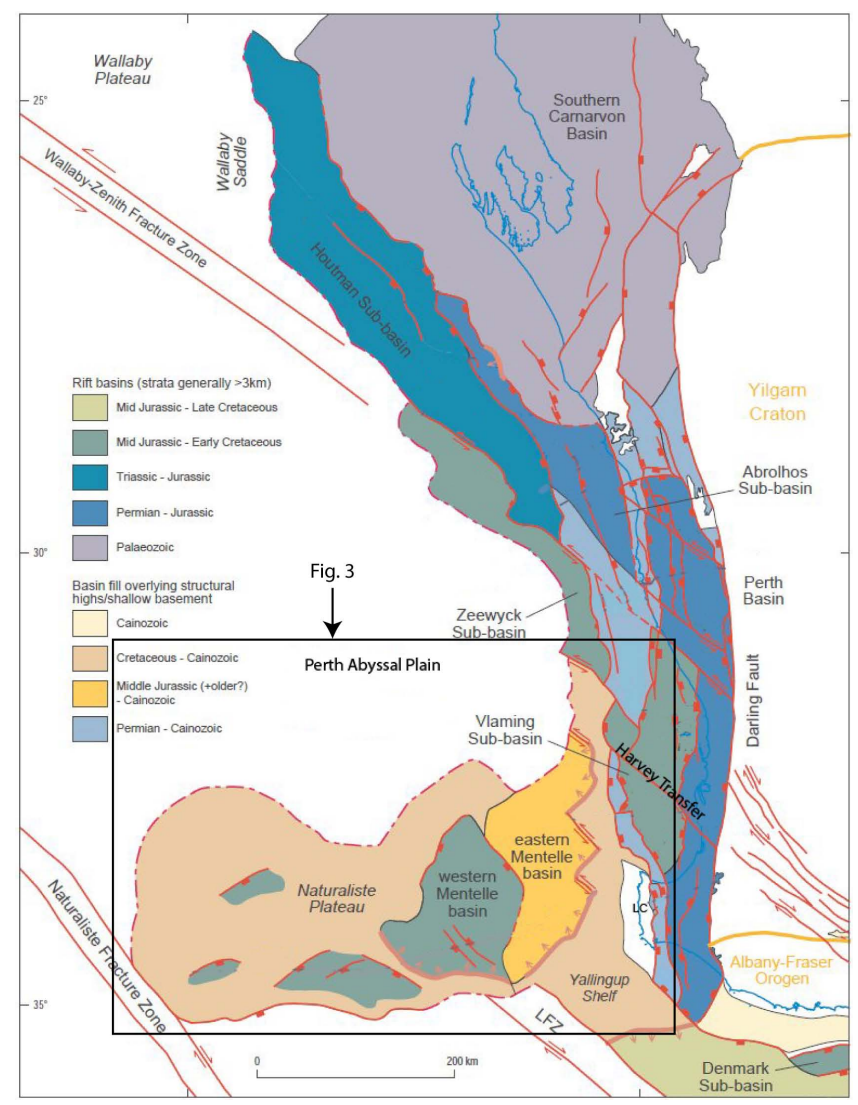

Fig. 2. Structural elements map of the area surrounding the Mentelle Basin. LFZ = Leeuwin Fracture Zone (modified from Bradshaw et al., 2003).

The Argo AP - Wallaby-Zenith Fracture Zone rifted margin to the north is volcanic in nature (Planke et al., 2000; Direen et al., 2007, 2008) (Figs. 1 and 2). South of the Houtman Sub-basin (Fig. 2) this margin becomes more complex, stepping westward across the basement-controlled Harvey Transfer Zone (Bradshaw et al., 2003), into the Mentelle Basin and the southern part of the Perth Basin (Fig. 2). The Vlaming Sub-basin is separated from the true margin by the crystalline basement high of the Leeuwin Complex and the Yallingup Shelf (Figs. 1 and 2).

This Valanginian-Late Hauterivian Australian-Antarctic conjugate rifted margin with India then stepped westward again to the western side of the Naturaliste Plateau-Bruce Rise and originally continued into the Princess Elizabeth Trough (Fig. 1) and farther west into the Enderby Basin. Here, the oldest true seafloor spreading anomalies are M9 (133 Ma - Hauterivian: timescale of Gradstein et al., 2004) (Stagg et al., 2004, 2005, 2006; Gaina et al., 2007), which are associated with seaward dipping reflector sequences (indicative of a volcanic margin) from the western flank of Bruce Rise to the Princess Elizabeth Trough (Stagg et al., 2006) (Fig. 1). These latter features predate Kerguelen Plateau volcanism and are associated with anomaly "M4" (= M5 of Ogg and Smith, 2004, 130 Ma: Barremian).
The character of the Perth margin to the north of the Mentelle Basin is not well constrained (Bradshaw et al., 2003), but is characterized by distribution of on and offshore volcanic rocks of the Bunbury Basalt (Frey et al., 1996; Coffin et al., 2002; Ingle et al., 2004; Gorter and Deighton, 2002) and is also considered to be a volcanic margin (e.g. Menzies et al., 2002). The Bunbury Basalt contains two geochemical age groupings: the older "Casuarina type" is $132.2 \pm 0.3 \mathrm{Ma}$ (Hauterivian) and the younger "Gosselin type" is $123 \mathrm{Ma}$ (Aptian) (Frey et al., 1996). The Gosselin type has been correlated with the Rajmahal Traps of eastern India (Coffin et al., 2002), which are dated at $118.1 \pm 0.3 \mathrm{Ma}$ (Kent et al., 1997, 2002) and are thought to be linked to mantle plume activity associated with the formation of the Kerguelen Plateau (Kent et al., 1997, 2002; Coffin et al., 2002).

From the Middle Jurassic during rifting and breakup of Greater India from Australia-Antarctica, the proto-Southern Rift System (SRS) (Stagg et al., 1990) situated south and east of the Mentelle Basin was undergoing extension. Syn-rift successions were deposited in the SRS at this time (Totterdell et al., 2000) and on the Naturaliste Plateau (Burkle, 1967; Borissova, 2002).

At around $95 \mathrm{Ma}$ (Cenomanian) (Duncan, 2002; Coffin et al., 2002) there was mafic volcanism and the onset of rifting of the Broken Ridge microcontinent from the Kerguelen Plateau, west of the Naturaliste Plateau (Royer and Coffin, 1992; Tikku and Cande, 1999, 2000). Final breakup between these features appears to have taken place at C34 time (Coniacian-Santonian: 85 Ma) (Tikku and Cande, 2000; Tikku and Direen, 2008). This ultimately resulted in the gradual propagation of the Southeast Indian Ridge System (e.g. Royer and Coffin, 1992; Gaina et al., 2007) to the southeast, forming a new magma poor margin and a continent ocean transition zone in the Diamantina Zone, south of the Mentelle Basin (Direen et al., 2008; Beslier et al., 2004) (Figs. 1 and 3), younging to the east (Tikku and Direen, 2008). In summary, the Mentelle Basin is a rifted continental margin basin, located at the southern end of the Hauterivian-Barremian volcanic margin formed between India and Australia-Antarctica. To the south, the Mentelle Basin is cross-cut by the younger Turonian-Maastrichtian magma-poor margin formed between Australia and Antarctica.

\section{Geophysical data}

\subsection{Data acquisition}

The earliest geophysical data recorded in the vicinity of the Mentelle Basin were magnetic and seismic refraction profiles acquired during a regional survey of the Perth Basin (Hawkins et al., 1965). Knowledge of the sedimentary and basement geometry was vastly improved by USNS Eltanin cruises (e.g. Hayes et al., 1975). These early acoustic profiles across the Naturaliste Plateau showed a thin acoustically 


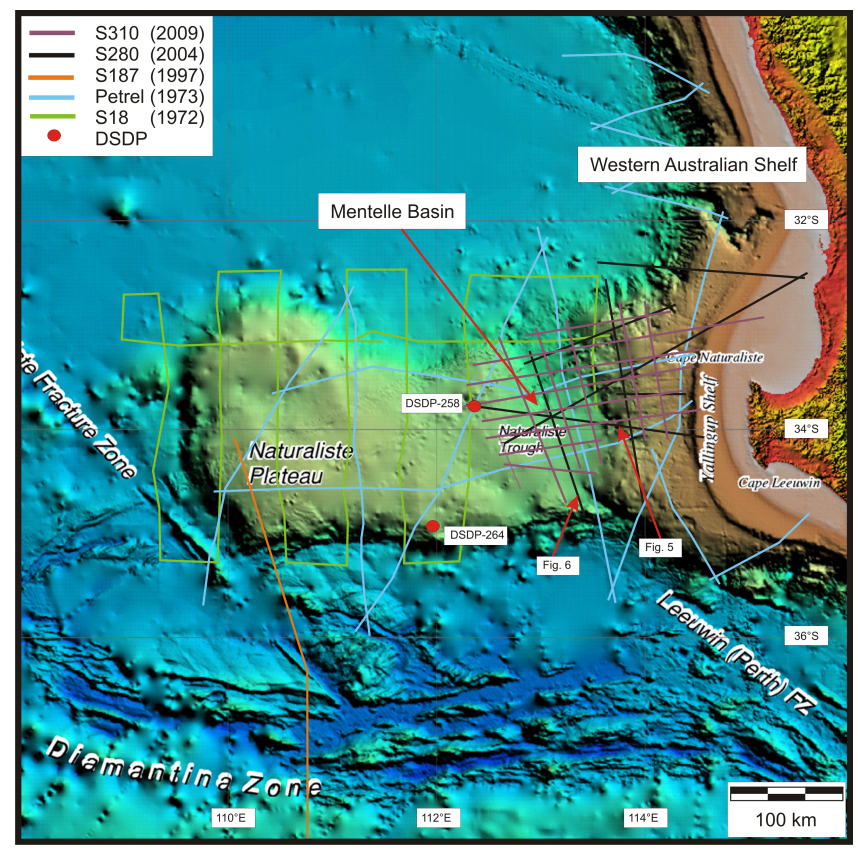

Fig. 3. Bathymetric map of the Mentelle Basin situated offshore Cape Leeuwin. The positions of the 2-D seismic surveys together with borehole locations are shown (modified from Borrissova, 2002).

transparent sedimentary cover above the acoustic basement defined by a rough, strongly reflecting surface (Petkovic, 1975). The first dense seismic program was the 1972 regional Geoscience Australia Continental Margins Survey 18. This survey consisted of a continuous set of seismic profiles, 8 orientated north-south and a further 9 aligned eastwest (Fig. 3), supplemented with continuous gravity, magnetic and bathymetric data. In the following year, the Shell Petrel Development Survey acquired four long profiles in approximately north-south orientations across the Naturaliste Plateau and Mentelle Basin (Fig. 3). These profiles were intersected by two east-west trending profiles that terminated on the Yallingup Shelf and are a subset of the Petrel survey that comprised a large series of overlapping profiles around the western and southern Australian margins. The older Shell Petrel Development Survey was acquired with a $1090 \mathrm{in}^{3}$ airgun array and a digital recording streamer, yielding a nominal fold of coverage of 24 with a $50 \mathrm{~m}$ common midpoint spacing image. No further seismic data was collected until 1997, when a single deep (16 s TWT) profile was undertaken as part of Geoscience Australia Survey 187, shot across the Diamantina Zone up on to the Naturaliste Plateau (Fig. 3).

Geoscience Australia survey S280 was acquired in 2004 using a tuned $4900 \mathrm{in}^{3}$ airgun array energy source and a 636 channel $7950 \mathrm{~m}$ seismic streamer digital recording system yielding a nominal fold of coverage of 80 with a $6.25 \mathrm{~m}$ common midpoint spacing. Seismic profiles extend onto the Western Australian Shelf and across the crystalline Yallingup
Shelf into the heavily faulted Vlaming Sub-basin (Figs. 2 and 3 ). Some seismic profiles pass close to borehole DSDP-258 on the eastern edge of the Naturaliste Plateau (Fig. 3), providing an important geological correlation tie-point for the final processed seismic stacked sections. In 2009, Geoscience Australia survey S310 was acquired (Borissova et al., 2010a). The S310 seismic survey was integrated with the older S280, S18 and Petrel surveys (Fig. 3) and borehole data to reappraise the stratigraphy, structural and depositional history of the Mentelle Basin. All seismic profiles displayed within have a vertical scale in s TWT.

\section{Methodology}

\subsection{Seismic data processing}

Raw shot records for the S18, "Petrel" and S280 seismic reflection surveys (Fig. 3) were reprocessed. Firstly, we present the processing sequence applied to the high-quality S280 survey that yielded high-resolution images of the sub-surface geology for subsequent re-interpretation (Fig. 4). Secondly, we present the processing of the older S18 and "Petrel" seismic surveys that gave poorer, but still significantly improved, final time-migrated stacked sections, which were used for closing the loops of interpreted horizons.

The acquisition set-up of the S280 survey produced a highquality dataset; however, the raw shots had to be conditioned with a $5 \mathrm{~Hz} @ 48 \mathrm{~dB} /$ octave low-cut filter to curtail spurious low-frequency internal instrumentation noise and random swell noise bursts. Using a minimum of processing steps, the objective was to maximise the temporal resolution of the thick Mentelle Basin sedimentary succession.

Two non-standard zero-phase filters were designed to remove the secondary source bubble pulse and frequency limiting ghost notches from the seismic data. In a stacked section, the secondary source bubble pulse is exhibited as a broad event sub-parallel to the seabed reflection cross-cutting primary geological reflections and potentially can be misinterpreted as a methane hydrate layer. The source debubble filter was applied to all shot records early in the processing sequence before demultiple, whereas the deghost filter was convolved with un-migrated post-stack data producing a flat amplitude spectrum of up to 4 octaves.

Deep water environment long-path multiples, though not a major artefact, were muted in Radon space (Russell et al., 1990). The long-path multiple suppression was aided by the power of the stack process and an inside trace mute on common midpoint gathers. Radon space demultiple also countered short-path multiples related to the high-amplitude Valanginian-Late Hauterivian breakup unconformity. Where S280 profiles passed across the shallow water West Australian Shelf, closely spaced water bottom generated reverberations were suppressed with a surface related multiple elimination algorithm (Verschuur et al., 1992). Pre-stack 


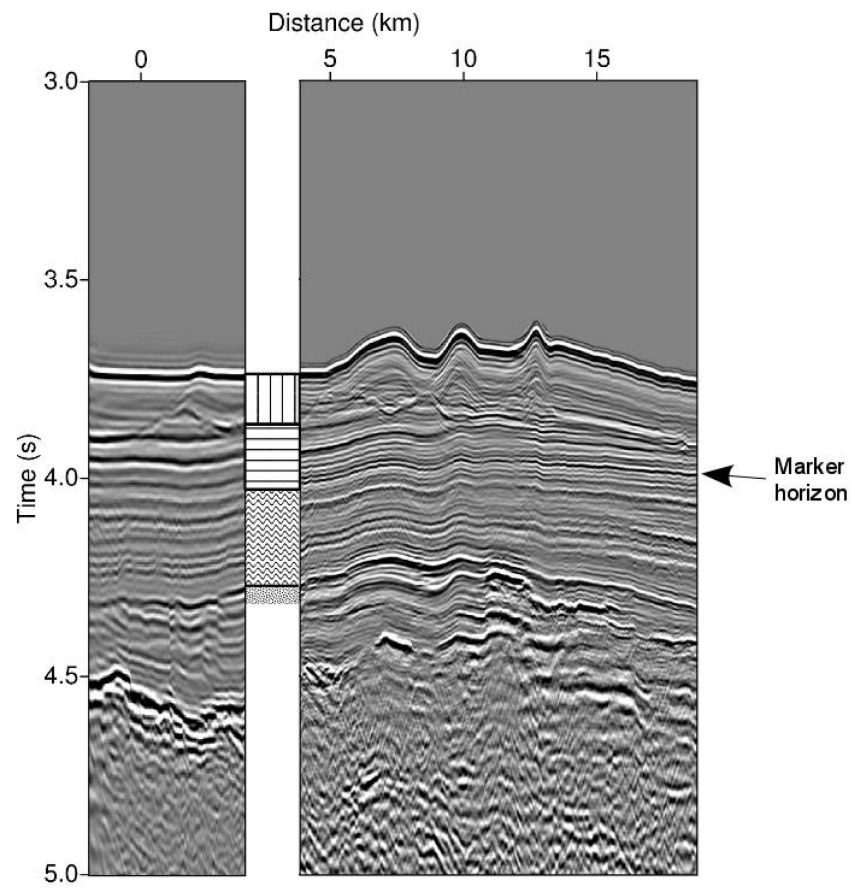

Fig. 4. DSDP-258 borehole data tied to the S280-501 seismic profile (seismic profile marked Fig. 5 in Fig. 3). The seismic profile to the left of the borehole represents the original data quality before reprocessing. The seismic profile to the right of the borehole shows the improved quality after data reprocessing. The marker horizon highlighted at about $4 \mathrm{~s}$ TWT marks a reflection doublet that is not resolvable on the original data, which after reprocessing is seismically resolvable across the whole Mentelle Basin. Within the lithological interpretation, vertical hatching represents $114 \mathrm{~m}$ of Miocene deepwater carbonates and oozes; horizontal hatching $171 \mathrm{~m}$ of limestones and chalks interdispersed with chert bands; wavy hatching Cretaceous black clays and the basal stippled region represents $11 \mathrm{~m}$ of Lower Cretaceous glauconitic sands (from Sargent et al., 2011).

reflection point smear was reduced by a Fourier domain implementation of dip moveout (Hale, 1984). The optimum Pwave stacking velocity field was interactively picked at $1 \mathrm{~km}$ intervals post-dip moveout. Post-stack time and spatially varying bandpass filtering suppressed unwanted spurious low and high-frequency noise, whereas spherical divergence and absorption wave energy loss was compensated by applying a smooth inverse amplitude decay curve along the length of each profile. The Kirchhoff time-migration algorithm was well suited to smooth Mentelle Basin P-wave stacking velocity field (Yilmaz, 2001). Prior to the time-migration process FX deconvolution (Canales, 1984) was required to prevent the relocation of out-of-plane diffractions destroying the continuity of the shallow geology.

The processing sequence applied to the Shell Petrel Development Survey was the same as that developed for the S280 survey, although the parameters were tailored to suit the lower data quality and narrower frequency bandwidth. The short $2400 \mathrm{~m}$ streamer favoured the use of the KarhunenLoève transform (Jones and Levy, 1987) to suppress multiple energy, rather than Radon demultiple. To aid the geological interpretation, the Petrel final time migrated sections were amplitude, phase and time matched to the S280 survey (Bishop and Nunns, 1994).

The Geoscience Australia Continental Margins Survey 18 raw 6-channel shot records dataset are of very low quality. Filters were designed to compress the complex $100 \mathrm{~ms}$ long $12 \mathrm{KJ}$ sparker energy source wavelet. Additional temporal resolution improvement was provided by post-stack zerophase spiking deconvolution. Sophisticated demultiple or dip moveout processing was not applied to the S18 dataset.

\section{Seismic observations}

The newly processed seismic data reveal at least $6.6 \mathrm{~s}$ TWT and up to a maximum of $7.8 \mathrm{~s}$ TWT of sedimentary column within the Mentelle Basin (Figs. 5 and 6). Major unconformities and seismic packages through the section that can be tied to the DSDP-258 borehole, together with regional variations in seismic character, have allowed us to divide the stratigraphy into major seismically derived tectonostratigraphic megasequences (Figs. 5 and 6). We describe each of these seismic megasequences and major unconformities below with regard to the stratigraphy and geological history of the Mentelle Basin from youngest to oldest respectively.

\subsection{Neogene (Miocene-Quaternary) megasequence}

The youngest megasequence in the Mentelle Basin comprises low-amplitude, thin, seafloor parallel reflections (Fig. 5). Seismic data analysis corroborates the borehole data that Neogene beds are regionally unconformable with underlying Cretaceous sediments. Neogene sediments are associated with deepwater carbonate oozes and pelagic sedimentation across the Mentelle Basin region. This megasequence typically forms a thin veneer across the basin reaching a maximum thickness of $0.5 \mathrm{~s}$ TWT within the main depocentre.

\subsection{Miocene unconformity}

The DSDP-258 borehole records a substantial hiatus of Miocene age that separates Neogene from Eocene sediments. The Miocene unconformity appears as an undulating surface on seismic data at which underlying subhorizontal Turonian-Santonian chalk beds subtly terminate. Directly eastward of the DSDP-258 borehole the Miocene unconformity is expressed as a sharp down-cutting reflection, with abrupt reflection terminations of Turonian-Santonian age chalk beds apparent. This unconformity then becomes seismically indistinguishable moving eastward across the Mentelle Basin, appearing conformable to underlying reflections; hence it is difficult to pick, particularly in the 

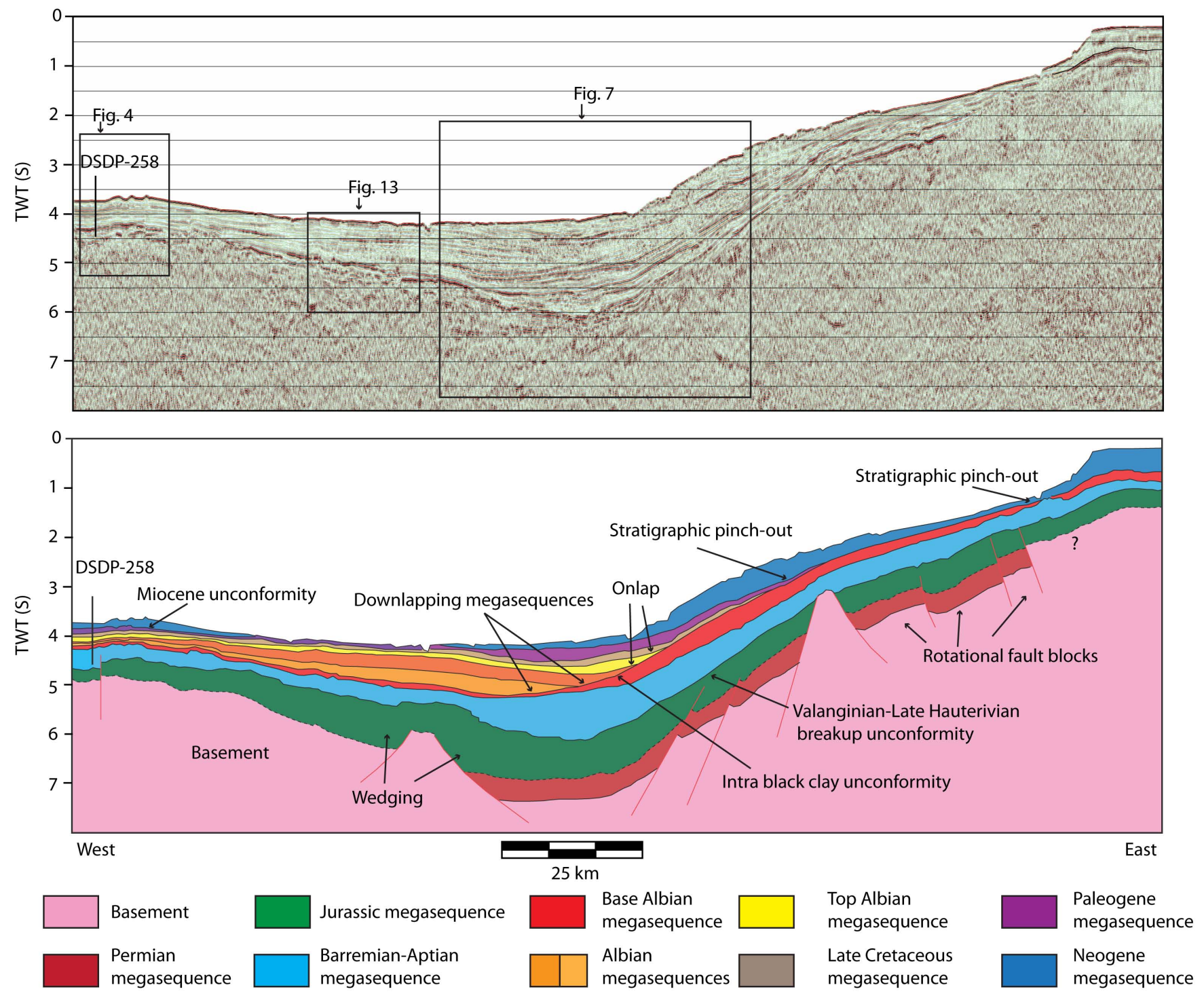

Fig. 5. (A) Uninterpreted dip section through the Mentelle Basin and (B) interpreted section of (A) depicting the architecture and characteristic of seismic megasequences, which constitute the Mentelle Basin fill. Basement structure is also displayed. A series of major unconformities are located within the centre of the Mentelle Basin upon which numerous megasequences onlap and pinchout.

low-resolution old vintage S18 and Petrel surveys. The geological time difference across this unconformity varies, reaching a maximum of $\sim 10 \mathrm{My}$ in the central area of the Mentelle Basin where thin Oligocene reflections terminate against the Miocene unconformity (Fig. 7).

\subsection{Palaeogene megasequence}

Adjacent to the slope of the Yallingup Shelf, a $\sim 350 \mathrm{~ms}$ TWT thick sub-basin, consisting of Oligocene and Eocene sediments, is seen to onlap onto the underlying Cretaceous megasequence (Fig. 7). Within this sub-basin, Eocene sediments are represented by a series of dipping reflections with a decreasing easterly dip, whose upper surfaces abruptly ter- minate at the Miocene unconformity. This sediment package is bound at its base by the Late Cretaceous megasequence. Close to the base of this megasequence is a major unconformity, marked by downlapping reflection terminations, which is interpreted to be Eocene in age. The Eocene unconformity is difficult to trace, appearing to trend parallel to bedding in the West and is diffuse towards the east, terminating upon the Western Australian Shelf. Palaeocene sediments are reported in borehole DSDP-264 (Hayes et al., 1975) (Fig. 3) and form part of a pelagic package up to $0.5 \mathrm{~s}$ TWT thick over the Naturaliste Plateau (Figs. 5 and 6). Internal higheramplitude reflections within this section may represent chert bands. These beds thin out rapidly at the southern scarp slope and more gradually on the gentle northern slope. In general, 

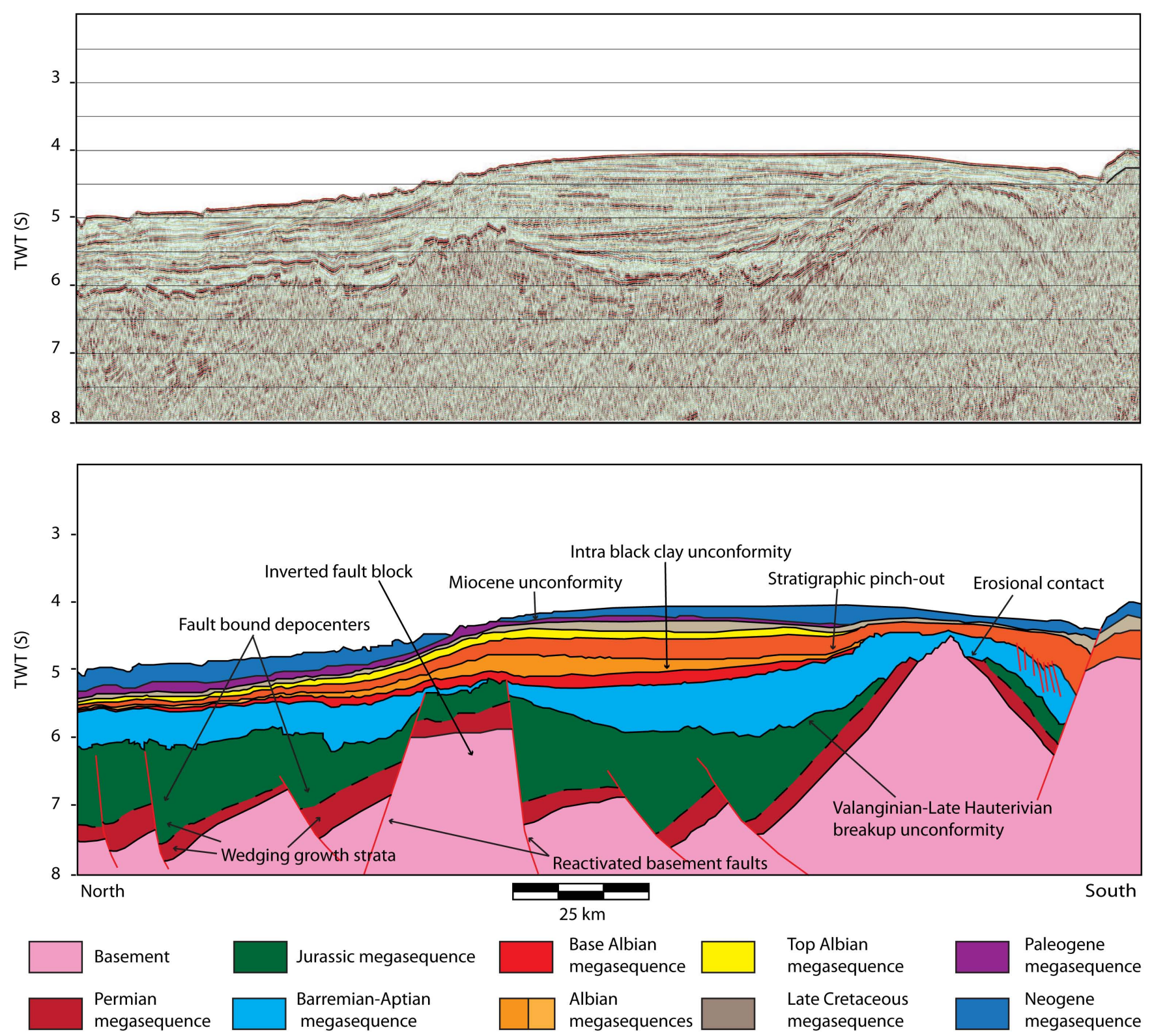

Fig. 6. (A) Uninterpreted and (B) interpreted strike line through the Mentelle Basin depicting the architecture of both the basement structure and seismically defined megasequences. Note the presence of a large inverted basement fault block situated close to the centre of the strike line.

sub-basins aside, the Palaeogene megasequence is characteristically thin across the Western Australian Shelf, draped unconformably on the underlying Cretaceous megasequences.

\subsection{Late Cretaceous- Eocene megasequences}

In the vicinity of the DSDP-258 borehole (Fig. 3) situated at $\sim 3.5 \mathrm{~s}$ TWT are a couplet of high-amplitude reflection combinations, which are identified as Turonian-Santonian chalk beds from the DSPD-258 borehole (Figs. 4 and 5). Regionally, these beds are relatively thin, ranging from close to zero in thickness to a maximum thickness of $\sim 1.5 \mathrm{~s}$ TWT. Within these chalk beds, high-amplitude reflection combinations are evident. The high-amplitude reflection doublet at just over $4 \mathrm{~s}$ TWT (Figs. 5 and 6) coincides with an increase in P-wave velocity, which is interpreted to represent chert beds logged at $220 \mathrm{~m}$ in borehole DSDP-258 (Luyendyk and Davies, 1974). Strong high-amplitude reflection events at $3.9 \mathrm{~s}$ and $3.8 \mathrm{~s}$ TWT may also represent chert bands. Within the central Mentelle Basin, the upper boundary of the Albian black clays is, in places, unconformable with overlying Palaeogene-Neogene sediments. The contact is marked by 

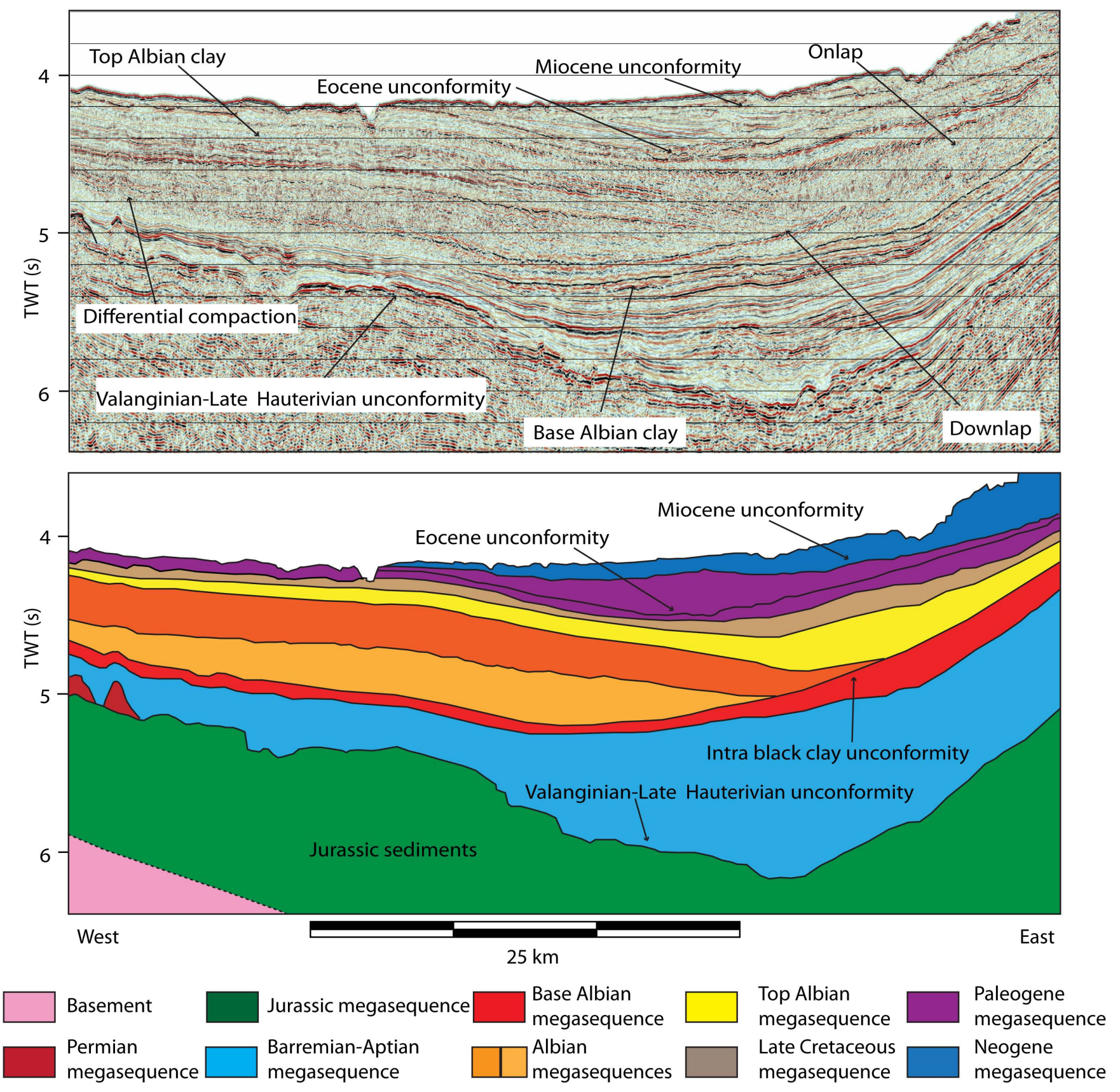

Fig. 7. (A) Uninterpreted and (B) interpreted seismic line showing the seismic characteristics and architecture of megasequences within the central Mentelle Basin.

reflections downlapping onto a sharp high-amplitude event whose acoustic impedance contrast is caused by Albian black clays and Turonian-Santonian chalk beds.

Immediately underlying the high-amplitude chert and chalk bands are a series of low amplitude parallel reflections. The contact between the Turonian-Santonian chalk and underlying black clays, dated Albian in age, is seismically diffuse. Close to borehole DSDP-258 the contact is represented by a $30 \mathrm{~m}$ gradational interface resulting in this boundary be- ing seismically indistinct (Fig. 5). In the immediate vicinity of the DSDP-258 borehole the Albian black clays themselves posses very little lithologic variation (Luyandyk and Davies, 1974). In contrast to the upper contact, a large P-wave velocity disparity between the Albian black clays and underlying $5 \mathrm{~m}$ thick bed of glauconitic sand ensures that the base Albian black clay is represented by a pronounced high-amplitude reflection situated at $\sim 4.3 \mathrm{~s}$ TWT, which can be traced across the entire Mentelle Basin (Figs. 5, 6 and 8). 


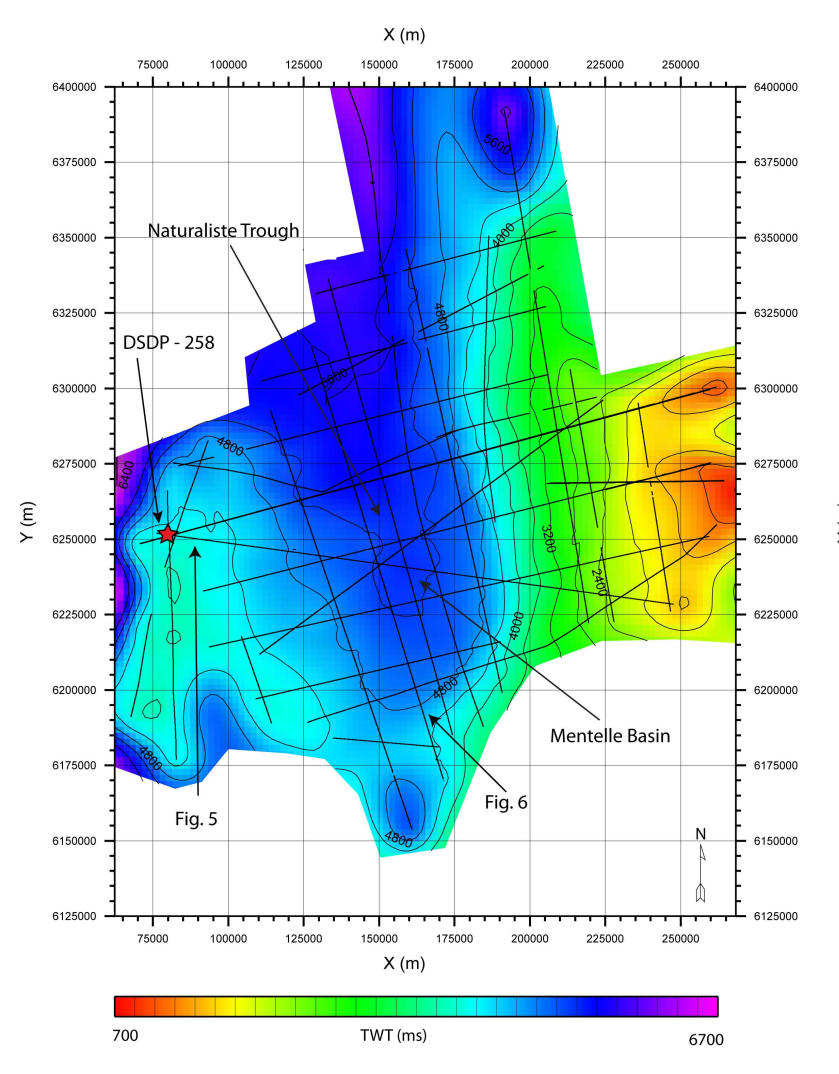

Fig. 8. TWT map of the basal reflection that defines the Base Albian megasequence.

The basal sedimentary succession intersected by borehole DSDP-258 is dated as Barremian-Aptian in age. On seismic data this succession is represented by washed-out subparallel seismic events of variable amplitudes (Figs. 4 and 5). DSDP-258 borehole data indicate that this succession is composed of interbedded silty sandy mudstones (Fig. 4). This succession thickens eastward to $\sim 1 \mathrm{~s}$ TWT at the base of the main Mentelle Basin depocentre (Fig. 7). The BarremianAptian megasequence can be correlated to adjacent contemporaneous sediments: a Cretaceous shale logged in the Vlaming Sub-Basin (e.g. Fig. 2). The Barremian-Aptian megasequence pinches out on the eastern slopes of the Naturaliste Plateau, although equivalent age deposits are interpreted to be in small discrete rift basins present on the Naturaliste Plateau (Borissova, 2002). These deposits probably have a different lithology since they are expressed seismically by a stronger, more defined reflection character when compared to Barremian-Aptian sediments imaged around DSDP-258 borehole (Figs. 5 and 7).

The internal architecture of the Cretaceous megasequences is not as homogeneous as it appears in the stratigraphy intersected by the DSDP-258 borehole, or on seismic profiles adjacent to it. The Cretaceous megasequences all wedge and thicken eastwards within the central Mentelle Basin depocenter and display considerable heterogeneity in their internal architecture as numerous unconformities, downlapping and onlapping reflection terminations are imaged. Where the combined thicknesses of the Cretaceous megasequences reach a maximum thickness of $900 \mathrm{~ms}$ TWT, within the central depocentre (Fig. 9), a thick succession of organic rich black clays has been deposited, which correlates with Albian black marine mudstones within the DSDP-258 borehole.

Overlying the base Albian black clay reflection in the central Mentelle Basin is a high-amplitude reflection combination, which dramatically cuts up-section over the Western Australian Shelf and typically separates underlying high-amplitude reflections from overlying eastward dipping, poorly resolved seismic reflections (Figs. 7 and 10). These eastward dipping reflections can be subdivided into three packages that onlap, downlap and terminate against the highamplitude reflection combination. This marks the highamplitude reflection combination as a major unconformity within the Albian clay, which does not coincide with the correlated base Albian clay interval. From herein this unconformity will be referred to as the "intra black clay unconformity", based upon its location within the stratigraphy. This unconformity pinches-out upon the Western Australian Shelf (Fig. 10).

The Late Cretaceous megasequence in the central Mentelle Basin onlaps and terminates against a distinct, high-amplitude reflection which continues up and over the Yallingup Shelf (Fig. 7). This megasequence is bound by both the top reflection defining the underlying downlapping megasequence and the intra black clay unconformity. It reaches a maximum thickness of $0.5 \mathrm{~s}$ TWT in the central depocentre and thins and pinches out over the Western Australian Shelf. Reflections situated internally within this package terminate against the top reflection of the underlying downlapping megasequence, which locally, also marks this top defining reflection as an unconformity within the central Mentelle Basin.

The three downlapping Cretaceous megasequences all thin westward, with reflections terminating upon the intra black clay unconformity. Cumulatively these three downlapping megasequences reach a maximum thickness of $0.8 \mathrm{~s}$ TWT in the main depocentre (Fig. 9). Here, the internal seismic character of the Albian black clays has a staccato appearance, reflection events are discontinuous and offset vertically on the millisecond scale at frequent intervals laterally (Fig. 7). These small scale features are the 2-D seismic representation of three-dimensional (3-D) polygonal faults that are common in thick deposits of fine grained materials (e.g. Cartwright and Dewhurst, 1998).

Eastwards, the contact between the Albian black clays are conformable with underlying Barremian-Aptian sediments before pinching out upon the Western Australian Shelf (Figs. 5 and 6). However, small wedges of Albian age sediments are interpreted to infill remnants of the small rift basins on the Naturaliste Plateau (Fig. 6). 

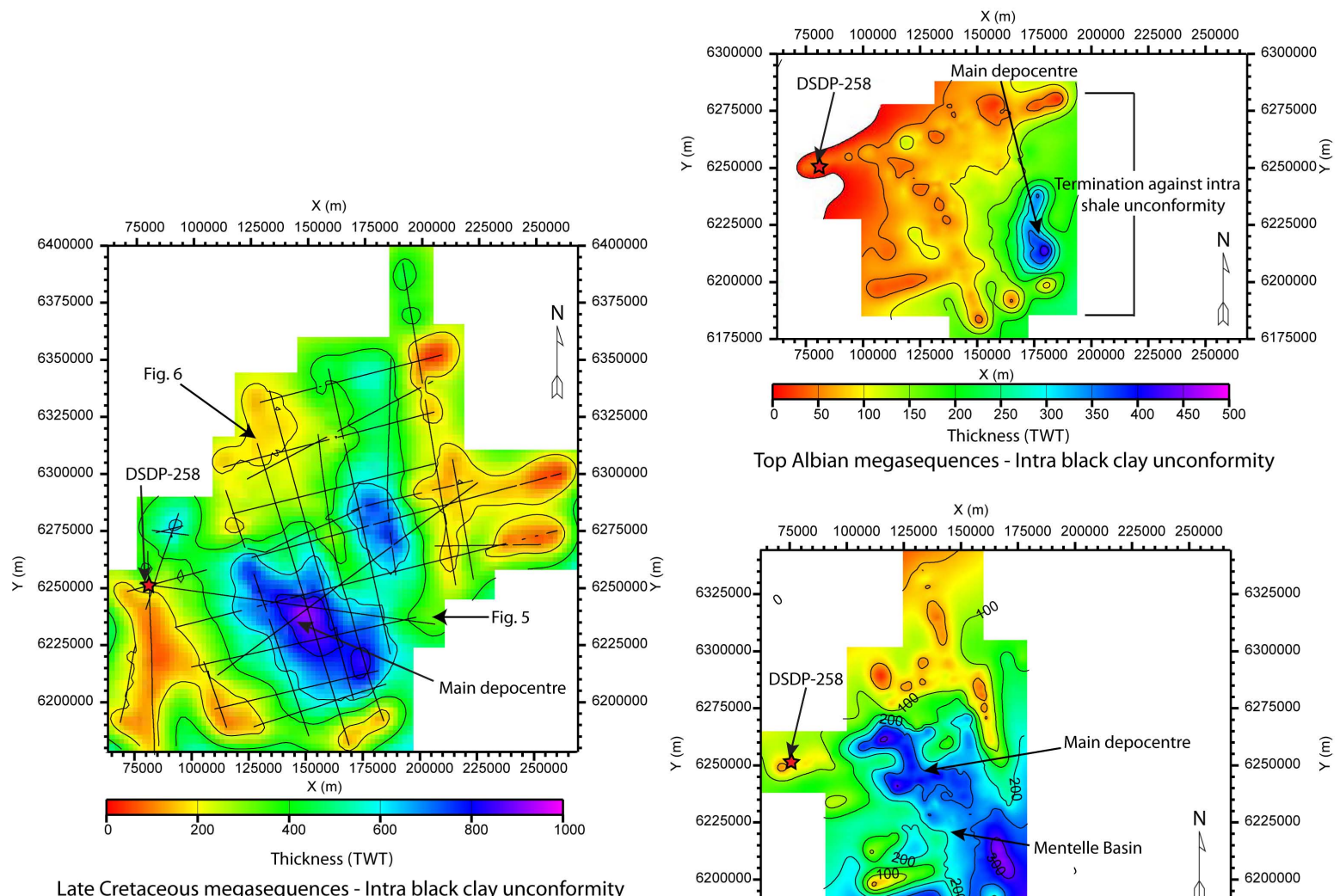

Top Albian megasequences - Intra black clay unconformity

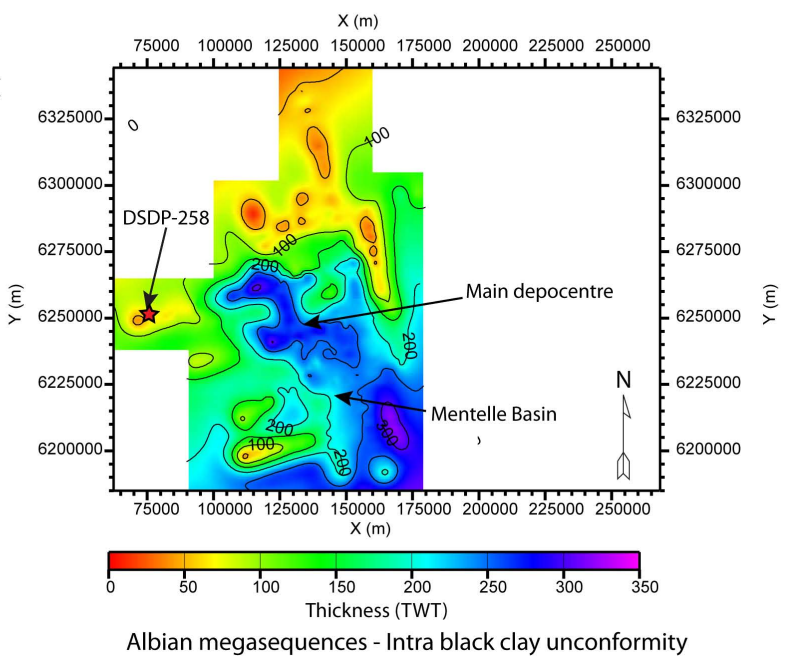

Fig. 9. Isochron maps for the Cretaceous black clay megasequences. Representative thickness changes highlighted within each isochron are interpreted to reflect changes in thermal contraction (flexure), subsidence and accommodation space.

\subsection{Valanginian-Late Hauterivian breakup unconformity}

A high-amplitude reflection situated at $\sim 4.5 \mathrm{~s}$ TWT (Figs. 5 and 7) is observable laterally across the Mentelle Basin (Fig. 11). This reflection displays numerous breaks in lateral continuity and is vertically offset indicating the presence of faults. This extensive horizon is interpreted as a Valanginian-Late Hauterivian unconformity associated with the breakup between India-Madagascar and AustraliaAntarctica (Borissova, 2002; Direen et al., 2008). This unconformity is thought to constitute a layer of volcanics, an interpretation that is reinforced from P-wave velocity analysis. P-waves travel typically through the Neogene-Paleogene pelagic deposits, Turonian-Santonian chalk beds and Albian black clays at $\sim 2000 \mathrm{~ms}^{-1}$ and through the BarremianAptian silty sandy mudstones at $\sim 2500 \mathrm{~ms}^{-1}$ (Fig. 12). The base of the Barremian-Aptian silty sandy mudstones is marked by a dramatic increase in P-wave velocity to $\sim 4000 \mathrm{~ms}^{-1}$, which is interpreted to reflect a hard crystalline lithology. Isolated high-amplitude reflections that curl up at the edges often overlie the Valanginian-Late Hauterivian breakup unconformity. The nature of these reflections is discussed further below.

Across the central Mentelle Basin, the Valanginian-Late Hauterivian breakup unconformity is overlain by several kilometre-scale moundal structures (Fig. 13). These mounds have various shapes, ranging from triangular/conical, to more laterally extensive square or convex topped platforms, with the larger structures generating seismic shadows. All of these structures display a high-amplitude leading edge, implying a hard compact lithology compared to the overlying drape of Cretaceous sediments and a "zig-zag christmas tree" structure (Fig. 13), which is interpreted to reflect the interdigitation of material forming between the mounds with adjacent Barremian-Aptian clastics. Further evidence that these mounds are composed of a hard lithology is given recorded by the excessive differential compaction systems evident within overlying sediments, which in places has led to the development of fine-scale fault systems propagating upwards through the Albian black clays. 


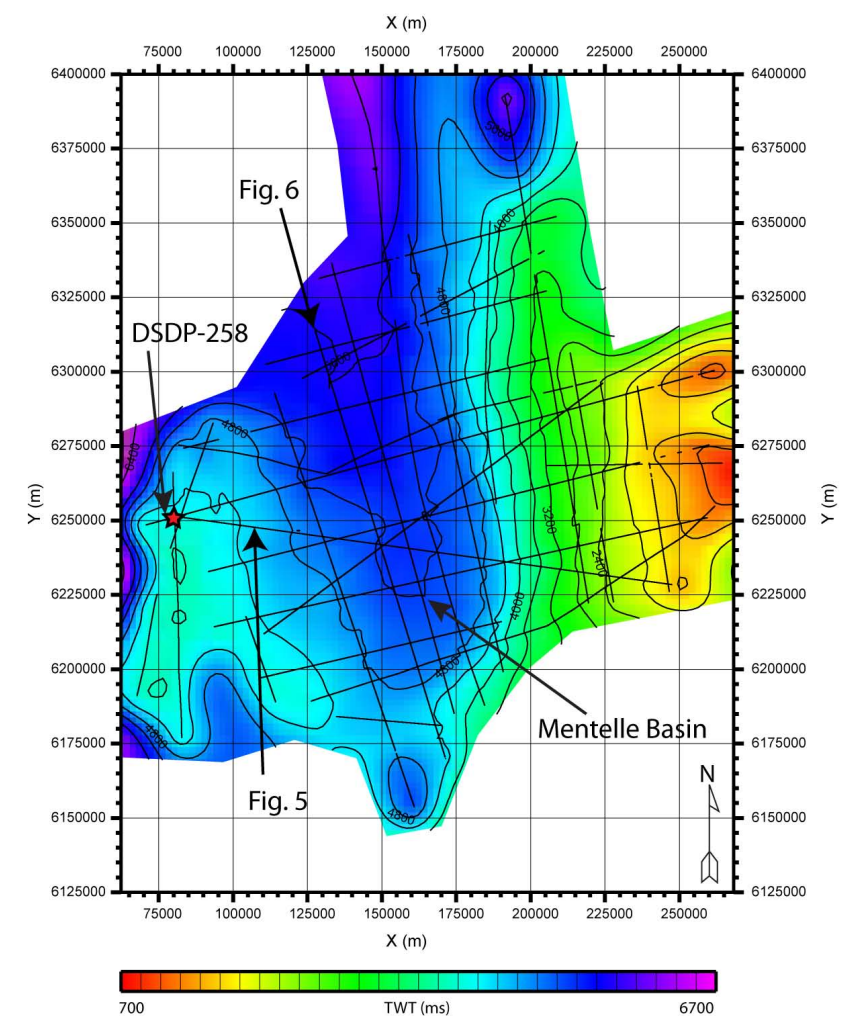

Fig. 10. TWT map of the intra black clay unconformity (within the Base Albian megasequence) upon which younger Cretaceous megasequences onlap.

\subsection{Jurassic megasequence}

A series of sub-parallel reflections are imaged below the high-amplitude Valanginian-Late Hauterivian breakup unconformity (Figs. 5 and 7). Seismic resolution below the Valanginian-Late Hauterivian breakup unconformity drops rapidly as a consequence of the overlying volcanic deposits. The Jurassic megasequence has a thickness of $\sim 0.8 \mathrm{~s}$ TWT and displays numerous breaks in lateral reflection continuity. Reflections are vertically offset along high angle discontinuities that indicate the presence of normal fault traces. The upper tip points of faults appear to terminate at the Valanginian breakup unconformity. These vertical reflection discontinuities resemble the geometry of rotated fault blocks. Jurassic reflection packages wedge and thicken into the hanging walls of fault blocks and are interpreted to be deposited during fault growth, coeval with Jurassic syn-rift extensional structures. Overlying contacts appear erosional where they terminate against the Valanginian-Late Hauterivian breakup unconformity (Fig. 6). This megasequence is laterally discontinuous throughout the Mentelle Basin, highly rotated and primarily situated within major depocentres. We interpret this Jurassic section to be contemporaneous with the Perth Basin fluvial sediments, the Eneabba Formation through to the cyclical muddy sandstone beds of the Yaragadee Formation (Iasky, 1993; Song and Cawood, 2000).

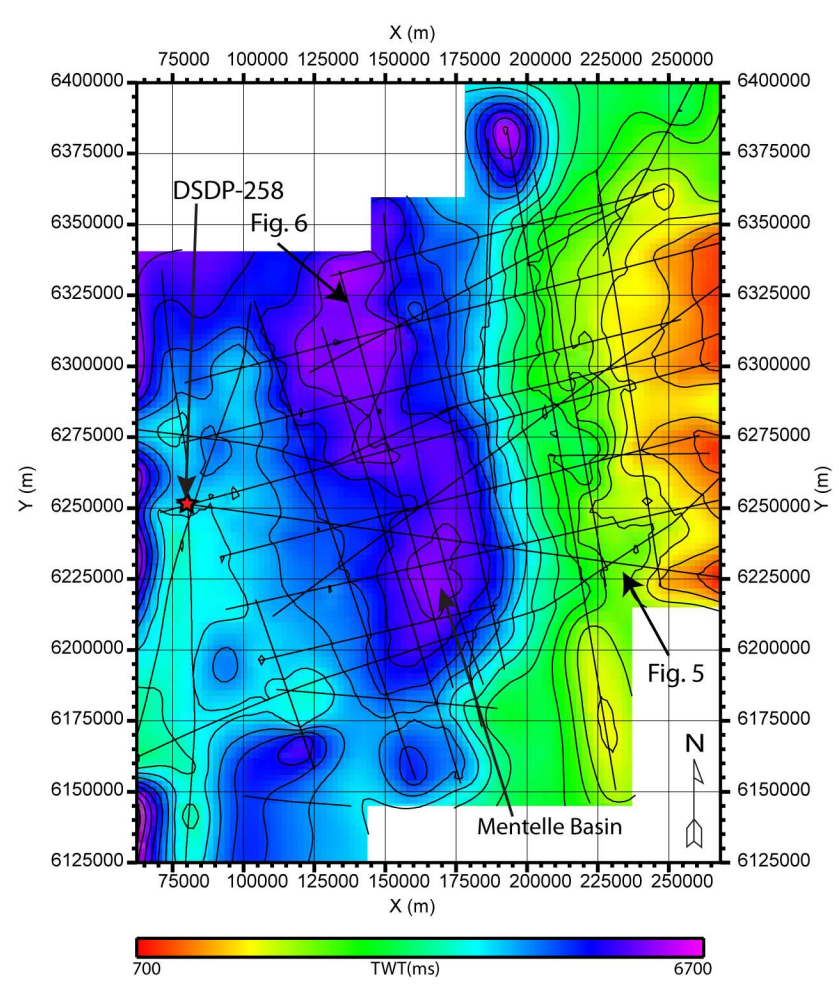

Fig. 11. TWT map of the Valanginian-Late Hauterivian breakup unconformity. This extensive unconformity can be mapped across the entire basin and marks a change from volcanic associated rifting to thermal subsidence and eventual deposition of black clays.

\subsection{Permian megasequence}

The Jurassic syn-rift is underlain by a much thicker megasequence that exhibits the same planar laminated seismic character, but is composed of dipping events that are discernable in the seismic section locally to $\sim 8 \mathrm{~s}$ TWT. The boundary between these two packages is primarily identified by a significant increase in P-wave interval velocity from $\sim 4000 \mathrm{~ms}^{-1}$ to $\sim 6000 \mathrm{~ms}^{-1}$ (Fig. 12), whereas on seismic data the contact between interpreted Jurassic and Permian sediment is broadly undistinguishable and so the contact is approximated by a dashed line on the seismic profiles shown (e.g. Figs. 5 and 6). The significant increase in P-wave interval velocity (Fig. 12) implies a hard, compacted lithology. This basal megasequence is also laterally discontinuous throughout the Mentelle Basin with Permian reflections only imaged within the major depocentre and fault bound grabens (Figs. 5 and 6). Further to the east, on the western flank of the crystalline Yallingup Shelf, steeply-dipping reflections are interpreted as Permian sedimentary rocks deposited in faultrotated and now peneplaned small internal basins. Other areas of the Mentelle Basin may also be underlain by older Permo-Triassic deposits; however these are mostly beyond the depth of seismic resolution with the data available to this study. Rotated reflections are imaged adjacent to hangingwalls of basement fault blocks where the megasequence 


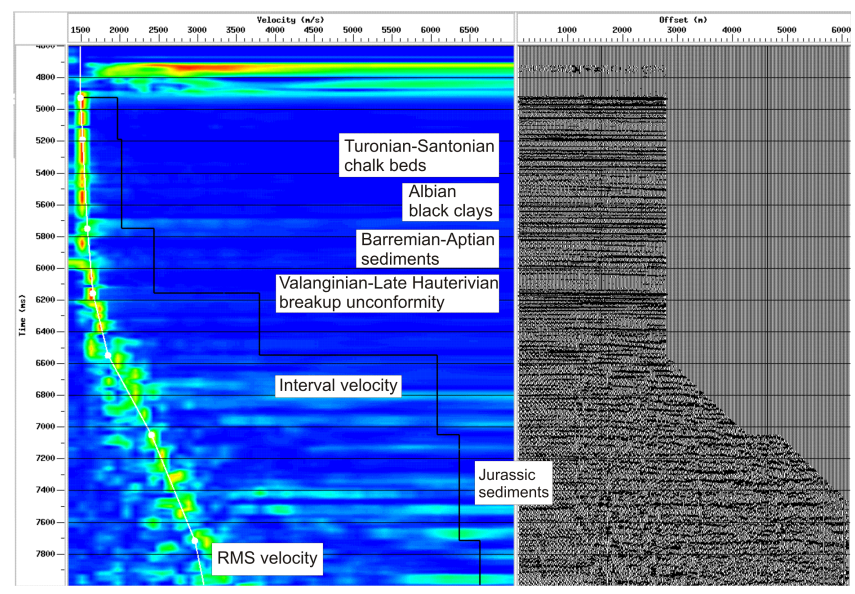

Fig. 12. Stacking and interval velocity trends for a typical depth profile through the Mentelle Basin. Note the significant increases in interval velocity associated with the Valanginian-Late Hauterivian breakup unconformity (volcanic composition) and deeper buried more compacted Jurassic sediments.

thickens. This thickening is interpreted to represent growth strata, identifying that deposition was synchronous with rifting, indicative of the increase in accommodation created in the hanging walls of normal faults. As intervals at this depth are generally dominated by seismic noise, where Permian age reflections are interpreted the contact with underlying Permo-Triassic deposits and/or the crystalline basement is approximated where coherent reflections are absent.

\section{Interpretation}

\subsection{Structural reappraisal of the Mentelle Basin}

Improving the seismic resolution of the older 2-D seismic data sets through reprocessing and combining reprocessed data with recently acquired 2-D data allowed the accurate definition of seismic megasequences to be correlated across the Mentelle Basin. This enabled the structural history of the Mentelle Basin to be reconstructed. Deep seated Jurassic and Permian megasequences are coincident with an early period of rifting and basin extension, wedging growth geometries show that Jurassic and Permian deposition was syn-kinematic with respect to fault growth. Erosional contacts between Permian and Jurassic megasequences and the Valanginian-Late Hauterivian breakup unconformity suggests subareal exposure of the India-Australian margin before breakup began.

The increase in P-wave velocity across the ValanginianLate Hauterivian breakup unconformity is consistent with the occurrence of an igneous lithology, likely to be basaltic in composition. The Valanginian-Late Hauterivian breakup unconformity is related to major rifting and volcanism involving the separation of India-Madagascar and Australia-
Antarctica. The isolated high-amplitude reflections that lie above the Valanginian unconformity displaying "smiles" are interpreted to be sills associated with breakup volcanism (Direen et al., 2008). The thickness of the basalt is assumed to be relatively thin, based on the fact that underling Permian and Jurassic megasequences are imaged, and because thick basaltic flows are known to degenerate seismic signal dramatically. Experience from the north-west Atlantic shows that hard compact basaltic horizons are difficult to seismically penetrate without special seismic acquisition parameters (Maresh and White, 2005) and/or special processing (Gallagher and Dromgoole, 2008).

It is conceivable that the high-amplitude kilometre-scale structures imaged upon the Valanginian-Late Hauterivian breakup unconformity reflection (Fig. 13) are of volcanic origin, contemporaneous with the Casuarina-type Bunbury Basalts, which have been dated at $132 \mathrm{Ma}$ (Hauterivian) (Frey et al., 1996), 4 to 8 m.y. younger than the ValanginianLate Hauterivian breakup age. Similar structures are observed in seismic data from the northern Perth Basin and have been interpreted as volcanic cinder cones (Gorter and Deighton, 2002). Degradation of the seismic signal occurs in places beneath the kilometre-scale structures; however, no volcanic feeder systems (dykes, climbing sills) (Direen et al., 2008) have been imaged. Coherent layer parallel reflections are imaged beneath some of these mounds, suggesting that such igneous intrusive features may be absent, although we caution that at the scale of observation and in the limitations of the signal to noise ratio that such features may be essentially undetectable, especially if they are sub-vertical.

Carbonate build-ups have similar seismological characteristics as basalts and so offer an alternative interpretation for the kilometre-scale pinnacle and flat topped structures (Fig. 13). 3-D seismic data from the Finnmark Platform has imaged sinuous, kilometre-wide Permo-Carboniferous reefs (Rafaelsen et al., 2008) and infilled atoll-like structures very similar in shape to the flat top structures imaged in the Mentelle Basin. Additionally, the characteristic "christmas tree" interdigitation between carbonate build-up and clastic apron may also support a carbonate origin for these features, although is not unequivocal. Ongoing ValanginianLate Hauterivian rift related subsidence may have led to a marine transgression in which large reefal structures could have flourished in a shallow, sediment-starved enclosed gulf.

Any reef building organisms existing in these waters would have been extinguished by the increasing turbidity as sediment flowed in westwards from the land. Proximal to the sediment supply source, the deposits are probably coarse grained relative to the distal silty sandy mudstones logged at the base of borehole DSDP-258, and form a complex unconformity surface produced by overlapping prograding fans and channel-cut fills (Fig. 11). These clastic deposits reach a maximum thickness of $\sim 1000 \mathrm{~m}$ in the $\sim 50 \mathrm{~km}$ diameter proto-Mentelle Basin, which indicates more rapid subsidence during the Barremian and Aptian than in the surrounding 


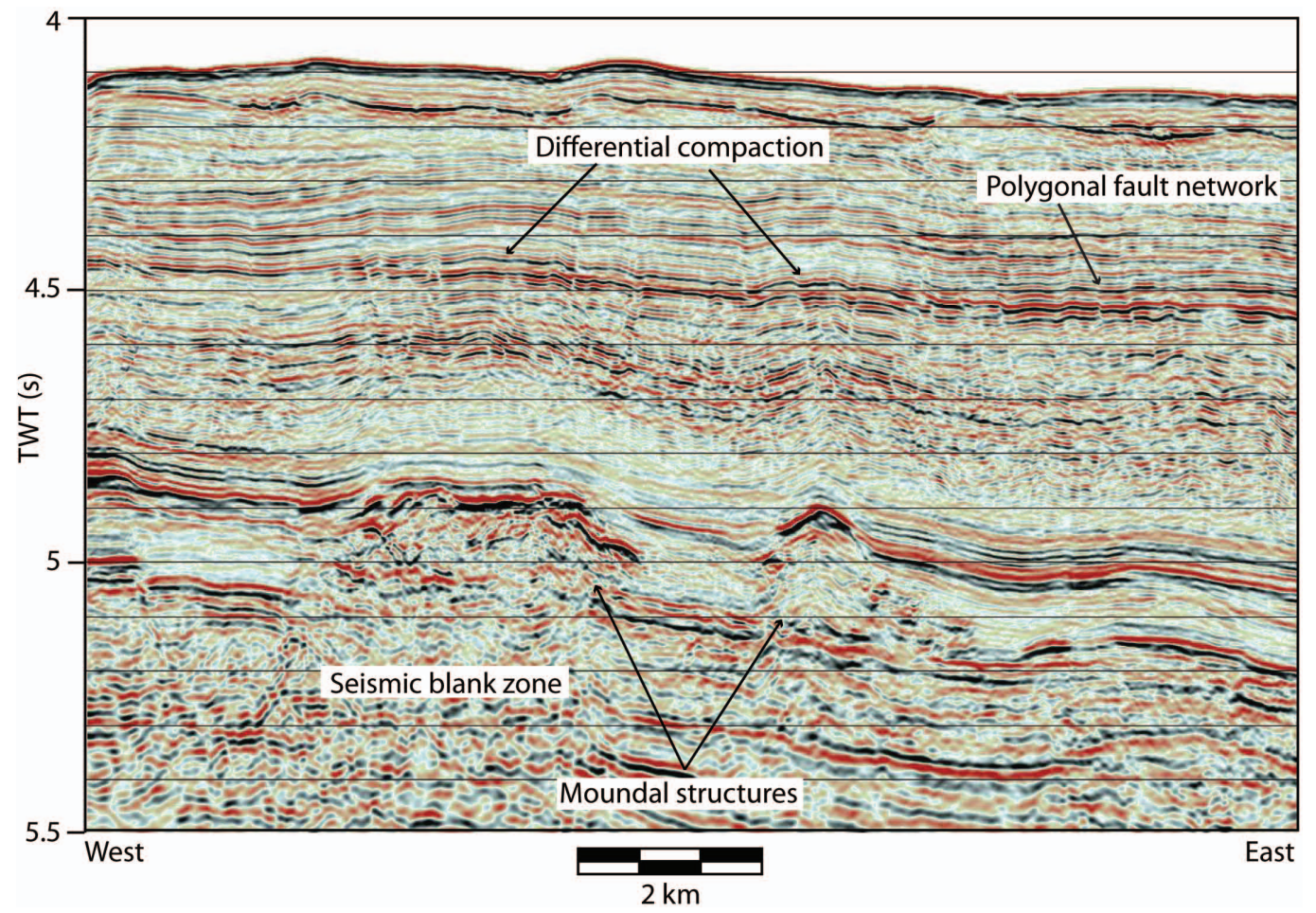

Fig. 13. Seismic line depicting moundal structures lying above the Valanginian-Late Hauterivian breakup unconformity. The extensive differential compaction system that has developed above the moundal structures implies that they are composed of a hard compact lithology.

area (Fig. 9). Beyond borehole DSDP-258, this sediment package pinches out on the eastern flanks of the Naturaliste Plateau, suggesting the latter feature may have been subaerial throughout the Barremian and Aptian.

The post breakup phase is represented by the thick succession of Cretaceous black clays. A critical observation is the presence of the downlapping and onlapping seismic megasequences and major unconformities, which define the internal architecture of Albian black clay megasequences in the central Mentelle Basin (Figs. 5 and 6). Previously, the Albian clays were interpreted to have been deposited in a thermally subsiding, open marine environment (Borissova, 2002), but the seismic megasequences imaged clearly show that basin history was more complex.

The Aptian-Barremian megasequence saw a change in deposition to open marine with the deposition of silty mudstones. Through the Albian, the Mentelle Basin was undergoing extension and subsidence as a consequence of the underlying the Kerguelen hotspot. The Kerguelen hotspot was particularly active throughout the Albian with an estimated magma flux of $0.9 \mathrm{~km}^{3} \mathrm{yr}^{-1}$ (Coffin et al., 2002), which rapidly built-up a massive basaltic platform. Heat flux from the Kerguelen hotspot is a possible cause for the thin continental crust in the vicinity of the Mentelle Basin as predicted by Direen et al. (2008). By the time of maximum magma output, plate motion resulted in the Kerguelen hotspot moving westwards relative to the Mentelle Basin leading to thermally relaxation-induced subsidence creating the central depocenter. Sediment input initially began from the east, with ferruginous source material eroded from the Bunbury Basalts, as determined by geochemical analysis (Luyendyk and Davies, 1974). The Aptian-Barremian megasequence is relatively thin and its upper surface is characterised by the intra black clay unconformity. This unconformity reflects a distinct change from open marine conditions and represents either: (1) a brief lowstand event, which led to an influx of coarse grained turbiditic material into the basin; or (2) margin flexure, as a consequence of thermal subsidence and/or sediment loading, which could have generated a turbidity flow in shelfal regions if accommodation was low.

Megasequences overlying the intra black clay unconformity both downlap and onlap upon the intra black clay unconformity and stratigraphically pinch-out over the Western Australian Shelf (Figs. 5, 6 and 7). This implies that a period of rapid subsidence followed and a return to open marine depositional conditions occurred. Onlap against the intra black clay unconformity displayed by the Late Cretaceous megasequences is likely to represent basin flexure and/or a rapid episode of subsidence, which was synchronous with deposition. The lack of any Albian black clays on the Naturaliste Plateau suggests that the plateau remained a structural high relative to the rapidly infilling Mentelle Basin during the Albian, as was the Western Australian Shelf. 
Throughout the Cenomanian, the region rapidly subsided to the present water depth of $\sim 3000 \mathrm{~m}$. This event is recorded in the stratigraphy in borehole DSDP- 258 as a $30 \mathrm{~m}$ transition zone from black clays to chalk beds (Fig. 4). It is hypothesised that rapid subsidence was caused by a loss of thermal buoyancy as the Kerguelen hotspot continued to move southwestwards (Weis et al., 2002).

The regional Eocene unconformity represents the breakup between Australia and Antarctica, an event that was highly diachronous (Tikku and Direen, 2008). South of the Mentelle Basin, breakup appears to have started prior to $\sim 95 \mathrm{Ma}$ (Beslier et al, 2004) and on the southern flank of the Naturaliste Plateau is recorded as a hiatus between PalaeoceneEocene deposits and underlying Turonian-Santonian chalk beds (Fig. 7) as detailed near borehole DSDP-258 (Fig. 4).

A later tectonic event disturbed the Mentelle Basin and surrounding region more dramatically. Middle Eocene magnetic anomalies present in the oceanic crust south of the eastwest orientated $250 \mathrm{~km}$ wide Diamantina Zone (Tikku and Cande, 1999) (Figs. 1 and 3) correspond to the separation of the Diamantina Zone and the Labuan Basin and the onset of fast spreading between Australia and Antarctica (Cande and Mutter, 1982; Royer and Coffin, 1992). The rapid northward motion of Greater India began $\sim 70 \mathrm{Ma}$ and once Greater India slowed in its northward migration $(\sim 50 \mathrm{Ma})$ the onset of fast spreading between Australia and Antarctica initiated (Cande and Mutter, 1982). The Middle-Eocene fast spreading event is interpreted to have tilted the Mentelle Basin region to the north. Tilting also appears to have reactivated some basement faults, including those controlling the geometry of the main depocentre within the Mentelle Basin. Figure 6 shows apparent inversion of a basement fault block where Jurassic sediments are in contact with Albian age sediments.

Subsequent to the establishment of the Eocene fast spreading, Australia's southern margin became a stable trailing margin (Totterdell et al., 2000). Miocene to Holocene deposits form a thin (200 ms TWT) veneer across the Mentelle Basin and Naturaliste Plateau and are interpreted to have been deposited on the stable trailing margin.

\section{Discussion}

\subsection{Climatic implications}

Geological records show that the Jurassic through to the Cretaceous was an exotic world compared to the present day. Tropical sea surface temperatures in the Late Albian to Turonian may have reached $35^{\circ} \mathrm{C}$ (Wilson et al., 2002); highlatitude sea surface temperatures were possibly in excess of $20^{\circ} \mathrm{C}$ (Huber et al., 1995). Atmospheric $\mathrm{CO}_{2}$ concentrations are thought to have been greater than $4000 \mathrm{ppm}$ (Bice and Norris, 2002) approximately 10 times the present day $\mathrm{CO}_{2}$ level. However, the existence of substantial carbonate pro- duction at high palaeolatitude $\sim 60^{\circ} \mathrm{S}$, if proven, would provide key insights into local oceanographic conditions during rifting. Climate modelling predicts temperatures of $\sim 30^{\circ} \mathrm{C}$ in the interior of the Australian-Antarctic land mass during the Early Cretaceous winter months (Fluteau et al., 2007). The high latitude Albian section within the Mentelle Basin may record such cycles, but this remains to be tested more fully.

\section{Conclusions}

Integration of new and vintage 2-D seismic datasets from the Mentelle Basin provided additional insights into the structural evolution of this poorly known and underexplored basin and has revealed hitherto unknown tectonostratigraphic features. Coherent seismically resolvable reflections forming the basal seismically defined megasequences are nested Jurassic-Lower Cretaceous and Permian rift basins. Truncating these meagasequences is a major regional angular unconformity, the Valanginian-Late Hauterivian breakup unconformity, which is overlain by constructional mounds that may be carbonate reefs, as opposed to a more conventional interpretation of volcanic features.

Above the Valanginian-Late Hauterivian breakup unconformity are a series of Cretaceous megasequences, which are separated by major unconformities. A thick succession of Albian age black clays is punctuated by the intra black clay unconformity. The intra black clay unconformity may reflect significant but short-lived lowstand event or margin flexure before a return to open marine conditions. Black clay deposition reflects the thermal contraction of the rifted margin basin, punctuated by thermal thinning events due to the presence of the Kerguelen plume; breakup in the Southern Rift System to the south; and the onset of Middle-Eocene fast spreading in the Australian-Antarctic Basin. The geological architecture of the Mentelle Basin was determined by this complex rifting history and its proximity to the migrating Kerguelen hotspot.

The presence of substantial Cretaceous carbonate buildups at high palaeolatitude, if proven, would also provide valuable data on local oceanographic conditions during and subsequent to continental breakup.

Acknowledgements. This Virtual Site Survey project was funded by NERC IODP-UK awarded to Richard Hobbs and Darren Gröcke (NERC reference number NE/G001332/1), in order to produce an IODP proposal for re-drilling the Naturalist Plateau. We show appreciation to Irina Borissova at Geoscience Australia for constructive scrutiny of the text. We also express gratitude to Bruce Goleby and Anne Fleming at Geoscience Australia for providing access to the raw seismic data for reprocessing. Landmark Graphics' ProMAX and SeisWorks software packages were used for seismic processing and interpretation. All the computing facilities at the Department of Earth Sciences were supported by 
Dave Stevenson and Gary Wilkinson. We also thank Steven Cande and Gary Wilson for their constructive comments, which helped improve the quality of this manuscript.

Edited by: V. Sallarès

\section{References}

Beslier, M. O., Royer, J. Y., Girardeau, J., Hill, P. J., Boeuf, E., Buchanan, C., Chatin, F., Jacovetti, G., Moreau, A., Munschy, M., Partouche, C., Robert, U., and Thomas, S.: Une large transition continent-ocean en pied de marge sud-ouest australienne: premiers resultats de la campagne MARGAU/MD110, Bulletin Societe geologique Francaise, 175, 629-641, 2004.

Bice, K. L. and Norris, R. D.: Possible atmospheric $\mathrm{CO}_{2}$ extremes of the Middle Cretaceous (late Albian-Turoninan), Paleooceanography, 17(4), doi:10.1029/2002PA000778, 2002.

Bishop, T. N. and Nunns, A. G.: Correcting amplitude, time and phase miss-ties in seismic data, Geophysics, 59, 946-953, 1994.

Borissova, I.: Geological framework of the Naturaliste Plateau, Geoscience Australia Record, 2002/20, 2002.

Borissova, I., Bradshaw, B. E., Nicholson, C, Struckmeyer, H. I. M., and Payne, D.: New exploration opportunities on the southwest Australian margin-deep-water frontier Mentelle Basin, APPEA J., 50, 1-13, 2010a.

Borissova, I., Bradshaw, B. E., Nicholson, C., Payne, D., and Struckmeyer, H. I. M.: Mentelle Basin - tectonic evolution controlled by of the combined extensional history of the Southwestern and Southern Australian margins, ASEG-PESA 21st Conference and exhibition, Sydney, 22-26 August 2010, Extended abstracts, 2010b.

Bradshaw, B. E., Rollet, N., Totterdell, J. M., and Borissova, I.: A revised structural framework for frontier basins on the southern and southwestern Australian continental margin, Geoscience Australia Record, 2003/03, 2003.

Burkle, L. H., Saito, T., and Ewing, M.: A Cretaceous (Turonian) core from the Naturaliste Plateau. Deep-Sea Res., 14, 421-426, 1967.

Canales, L.: Random noise reduction: 54th Annual International Meeting, Society of Exploration Geophysicists, Expanded Abstracts, 525, 1984.

Cande, S. C. and Mutter, J. C.: A revised identification of the oldest sea-floor spreading anomalies between Australia and Antarctica, Earth Planet. Sci. Lett., 58, 151-160, 1982.

Cartwright, J. A. and Dewhurst, D. N. Layer-bound compaction faults in fine-grained sediments, GSA Bull., 110, 1242-1257, 1998.

Coffin, M. F., Pringle, M. S., Duncan, R. A., Gladczenko, T. P., Storey, M., Müller, R. D., and Gahagan, L. A.: Kerguelen hotspots magma output since 130 Ma, J. Petrol., 43, 1121-1139, 2002.

Direen, N. G., Borissova, I., Stagg, H. M. J., Colwell, J. B., and Symonds, P. A.: Nature of the continent-ocean transition zone along the southern Australian continental margin: a comparison of the Naturaliste Plateau, SW Australia, and the central Great Australian Bight sectors, in: Imaging, mapping and modelling continental lithosphere extension and breakup, edited by: Karner,
G. D., Manatschal, G., and Pinheiro, L. M., Geological Society (London) Special Publication, 282, 235-261, 2007.

Direen, N. G., Stagg, H. M. J., Symonds, P. A., and Colwell, J. B.: The architecture of volcanic rifted margins: new insights from the Exmouth-Gascoyne margin: Western Australia, Aust. J. Earth Sci., 55, 325-347, 2008.

Direen, N. G., Borissova, I., Stagg, H. M. J., Colwell, J. B., and Symonds, P. A.: Nature of the continent - ocean transition zone along the southern Australian continental margin, in: Imaging, mapping and modelling continental lithosphere extension and breakup, edited by: Karner, G. D., Manatschal, G., and Pinheiro, L. M., Geological Society (London) Special Publication, 282, 235-261, 2007.

Direen, N. G., Stagg, H. M. J., Colwell, J, B., and Symonds, P. A.: Dominant Symmetry of a Conjugate Southern Australian and East Antarctic MagmaPoor Rifted Margin Segment. Geochem. Geophys. Geosys., (G3) 12(2) doi:10.1029/2010GC003306, 2011.

Duncan, R. A.: A time frame for construction of the Kerguelen Plateau and Broken Ridge, J. Petrol., 43, 1109-1119, 2002.

Fluteau, F., Ramstein, G., Besse, J., Guirand, R., and Masse, J. P.: Impacts of palaeogeography and sea level changes on MidCretaceous climate, Palaeogeogr., Palaeocl., Palaeoecol., 247, 357-381, 2007.

Frey, F. A., McNaughton, N. J., Nelson, D. R., delaeter, J. R., and Duncan, R. A.: Petrogenesis of the Bunbury Basalts, Western Australia: interaction between the Kerguelen plume and Gondwana lithosphere?, Earth Planet. Sci. Lett., 176, 73-89, 1996.

Gaina, C., Mueller, R. D., Brown, B., Ishihara, T., and Ivanov, S.: Breakup and early seafloor spreading between India and Antarctica, Geophys. J. Internat., 170, 151-169, 2007.

Gallagher, J. W. and Dromgoole, P. W.: Seeing below the basalt offshore Faroes, Geophys. Prospect., 56, 33-45, 2008.

Gorter, J. D. and Deighton, I.: Effects of igneous activity in the offshore northern Perth Basin - evidence from petroleum exploration wells, 2-D seismic and magnetic surveys, in: Western Australian Basins Symposium III, edited by: Keep, M. and Moss, S. J., PESA, Perth, 875-899, 2002.

Gradstein, F. M., Ogg, J. G., and Smith, A. G.: A Geological Time Scale, Cambridge University Press, New York, 2004.

Hale, D.: Dip moveout by Fourier transform, Geophysics, 49, 749757, 1984.

Halpin, J. A., Crawford, A. J., Direen, N. G., Coffin, M. F., Forbes, C. J., and Borissova, I.: Naturaliste Plateau, offshore Western Australia: A submarine window into Gondwana assembly and breakup, Geology., 36, 807-810, 2008.

Hawkins, L. V., Hennion, J. F., Nafe, J. E., and Thyer, R. F.: Geophysical investigation in the area of the Perth Basin, Western Australia, Geophysics., 30, 1026-1052, 1965.

Hayes, D. E., Frakes, L. A., and Barrett, P. J.: Shipboard site reports, site 264. Initial reports of the Deep Sea Drilling Project, Leg 28, Washington, D.C., U.S. Government Printing Office, 1975.

Huber, B. T., Hodell, D. A., and Hamilton, C. P.: Middle-Late Cretaceous climate of the southern high latitudes: Stable isotopic evidence for minimal equator-to-pole thermal gradients, Geol. Soc. Am. Bull., 107, 1164-1191, 1995.

Ingle, S., Scoates, J. S., Weis, D., Brugmann, G., and Kent, R. W.: Origin of Cretaceous continental tholeiites in southwestern Australia and eastern India: insights from $\mathrm{Hf}$ and Os isotopes, Chem. 
Geol., 209, 83-106, 2004.

Iasky, R. P.: A structural study of the Southern Perth Basin, Western Australia, Geological Survey of Western Australia, Report 31, 1993.

Johnston, S., Hackney, R., and Nicholson, C., Distribution of volcanic facies and results from potential field modelling of the Mentelle Basin, southwestern Margin, Australia, ASEG-PESA 21st Conference and exhibition, Syndey, 22-26 August 2010, Extended abstracts, 2010.

Jones, I. F. and Levy, S.: Signal-to-noise ratio enhancement in multichannel seismic data via the Karhunen-Loève transform, Geophys. Prospect., 35, 12-32, 1987.

Jongsma, D. and Petkovic, P.: The structure of the Naturaliste Plateau and trough, The APPEA J., 17 Part 1, 3-12, 1977.

Kent, R. W., Saunders, A. D., Kempton, P. D., and Ghose, N. C.: Rajmahal basalts, eastern India: mantle sources and melt distribution at a volcanic rifted margin, in: Large Igneous Provinces: Continental, Oceanic and Planetary Flood Volcanism, edited by: Mahoney, J. J. and Coffin, M. F., American Geophysical Union Geophysical Monograph, 100, 145-182, 1997.

Kent, R., Pringle, M. S., Müller, R. D., Saunders, A. D., and Ghose, N. C.: ${ }^{40} \mathrm{Ar} /{ }^{39} \mathrm{Ar}$ geochronology of the Rajmahal basalts, India and their relationship to the Kerguelen Plateau, J. Petrol., 43, 1141-1153, 2002.

Luyendyk, B. P. and Davies, T. A.: Shipboard site reports, site 258. Initial reports of the Deep Sea Drilling Project, Leg 26, Washington, D.C., U.S. Government Printing Office, 1974.

Maresh, J. and White, R. S.: Seeing through a glass, darkly: strategies for imaging through basalt, First Break., 23(5), 27-33, 2005.

Markl, R. G.: Further evidence for the Early Cretaceous breakup of Gondwanaland off southwestern Australia, Mar. Geol., 26, 4148, 1978.

Menzies, M. A., Klemperer, S. L., Ebinger, C., and Baker, J.: Characteristics of volcanic rifted margins, in: Volcanic Rifted Margins, edited by: Menzies, M. A., Klemperer, S. L., Ebinger C., and Baker J., Geological Society of America Special Paper, 362, 1-14, 2002.

Metcalfe, I.: Gondwanaland dispersion, Asian accretion and evolution of eastern Tethys, Aust. J. Earth Sci., 43, 605-624, 1996.

Mihut, D. and Mueller, R. D.: Volcanic margin formation and Mesozoic rift propagators in the Cuvier abyssal plain off Western Australia, J. Geophys. Res, B, Solid Earth and Planets., 103, 27135-27149, 1998.

Mutter, J. C., Larson, R. L., Buhl, P., Diebold, J. B., Alsop, J., Lorenzo, J. M., Mithal, R., Hopper, J., Falvey, D. A., Williamson, P. E., Brassil, F., and Northwest Australia Study Group: Extension of the Exmouth Plateau, offshore northwestern Australia; deep seismic reflection/refraction evidence for simple and pure shear mechanisms, Geology., 17, 15-18, 1989.

Ogg, J. G. and Smith, A.: The geomagnetic polarity timescale, in: A Geologic Time Scale, edited by: Gradstein, F. M., Ogg, J. G., and Smith A., Cambridge University Press, pp. 589, 2004.

Petkovic, P.: Origin of the Naturaliste Plateau, Nature, 253, 30-33, 1975.

Planke, S., Symonds, P. A., Alvestad, E., and Skogseid, J.: Seismic volcanostratigraphy of large volume basaltic extrusive complexes on rifted margins, J. Geophys. Res., 105, 19335-19351, 2000 .
Powell, C. M., Roots, S. R., and Veevers, J. J.: Pre-breakup continental extension in East Gondwanaland and the early opening of the eastern Indian, Ocean. Tectonophysics., 155, 261-283, 1988.

Rafaelsen, B., Elvebakk, G., Andreassen, K., Stemmerik, L., Colpaert, A., and Samuelsberg, T. J.: From detached to attached carbonate buildup complexes-3D seismic data from the upper Palaeozoic, Finnmark Platfrom, southwestern Barents Sea, Sed. Geol., 206, 17-32, 2008.

Royer, J.-Y. and Coffin, M. F.: Jurassic to Eocene plate tectonic reconstructions in the Kerguelen Plateau region, in: Proceedings of the Ocean Drilling program, edited by: Wise, S. W., Schlich, R., and Julson, A. A. P., Scientific Results, 120, College Station, 1992.

Russell, B., Hampson, D., and Chun, J.: Noise elimination and the Radon transform: The Leading Edge, 9(10), 18-23, 1990.

Sargent, C., Hobbs, R. W., and Gröcke, D. R.: Improving the interpretability of air-gun seismic reflection data using deterministic filters: A case history from offshore Cape Leeuwin, southwest Australia, SEG, 76(3), B113-B125, doi:10.1190/1.3554396, 2011.

Song, T. and Cawood, P. A.: Structural styles in the Perth Basin associated with the Mesozoic break-up of Greater India and Australia, Tectonophysics., 317, 55-72, 2000.

Stagg, H. M. J., Willcox, J. B., Needham, D. J. L., O’Brien, G. W., Cockshell, C. D., Hill, A. J., Thomas, B., and Hough, L. P.: Basins of the Great Australian Bight region: geology and petroleum potential. Continental Margins Program Folio 5. Bureau of Mineral Resources, Geology and Geophysics and Department of Mines and Energy, South Australia, 1990.

Stagg, H. M. J., Alcock, M. B., Bernardel, G., Moore, A. M. G., Symonds, P. A., and Exon, N. F.: Geological framework of the outer Exmouth Plateau and adjacent ocean basins, Geoscience Australia Record, 2004/13, 2004.

Stagg, H. M. J., Colwell, J. B., Direen, N. G., O'Brien, P. E., Bernardel, G., Borissova, I., Brown, B. J., and Ishihara, T.: Geology of the continental margin of Enderby and Mac. Robertson Lands, East Antarctica, Insights from a regional data set, Mar. Geophys. Res., 25, 183-219, 2005.

Stagg, H. M. J., Colwell, J. B., Borissova, I., Ishihara, T., and Bernardel, G.: The Bruce Rise Area, East Antarctica: Formation of a Continental Margin near the Greater India - Australia Antarctica Triple Junction, Terra Antarctica., 13, 3-22, 2006.

Tikku, A. A. and Cande, S. C.: The oldest magnetic anomalies in the Australian-Antarctic Basin, Are they isochrons? J. Geophys. Res., 104, 661-677, 1999.

Tikku, A. A. and Cande, S. C.: On the fit of Broken Ridge and Kerguelen Plateau, Earth Planet. Sci. Lett., 180, 117-132, 2000.

Tikku, A. A. and Direen, N. G.: Comment on "Major AustralianAntarctic Plate Reorganization at Hawaiian-Emperor Bend Time", Science, 321, 490-491c, 2008.

Totterdell, J. M., Blevin, J. E., Struckmeyer, H. I. M., Bradshaw, B. E., Colwell, J. B., and Kennard, J. M.: A new stratigraphic framework for the Great Australian Bight: starting with a clean slate, APPEA J., 40, 95-117, 2000.

Veevers, J. J. and Li, Z. X.: Review of seafloor spreading around Australia. II. Marine magnetic anomaly modeling, Aust. J. Earth Sci., 38, 391-408, 1991. 
Verschuur, D. J., Berkhout A. J., and Wapenaar, C. P. A.: Adaptive surface-related multiple elimination, Geophysics., 57, 11661177, 1992.

Weis, D., Frey, F. A., Schlich, R., Schaming, M., Montigny, R., Damasceno, D., Mattielli, N., Nicolaysen, K. E., and Scoates, J. S.: Trace of the Kerguelen mantle plume: Evidence from seamounts between the Kerguelen Archipelago and Heard Island, Indian Ocean. Geochem. Geophys. Geosys., G3 3(6), 1033, doi:10.1029/2001GC000251, 2002.
Wilson, P. A., Norris, R. D., and Cooper, M. J.: Testing the Cretaceous greenhouse hypothesis using glassy foraminiferal calcite from the core of the Turonian tropics Demerara Rise, Geology., 30, 607-610, 2002.

Yilmaz, O.: Seismic Data Analysis: Processing, Inversion, and Interpretation of Seismic data, Vol. 1, SEG., 2001. 